\title{
Development of core collection in pigeonpea [Cajanus cajan (L.) Millspaugh] using geographic and qualitative morphological descriptors
}

\author{
L.J. Reddy, Hari D. Upadhyaya, C.L.L. Gowda and Sube Singh \\ International Crops Research Institute for the Semi-Arid Tropics (ICRISAT), P.O. Patancheru 502324 , \\ Andhra Pradesh, India; *Author for correspondence (e-mail: H.Upadhyaya@CGIAR.ORG)
}

Received 13 October 2003; accepted in revised form 10 January 2004

Key words: Cajanus cajan, Core collection, Genetic resources, Redgram

\begin{abstract}
Pigeonpea is an important pulse crop grown by smallholder farmers in the semi-arid tropics. Most of the pigeonpea cultivars grown to date are selections from the landraces, with a narrow genetic base. With the expansion of the crop to newer areas, problems of local importance are to be addressed. Hence, an economically feasible and faster germplasm evaluation mechanism, such as a core collection, is required. This article describes the development of core collection from 12,153 pigeonpea accessions collected from 56 countries and maintained at ICRISAT, Patancheru, India. The germplasm accessions from 56 countries were placed under 14 clusters based primarily on geographic origin. Data on 14 qualitative morphological traits were used for cluster formation by Ward's method. From each cluster $\approx 10 \%$ accessions were randomly selected to constitute a core collection comprising 1290 accessions. Mean comparisons using Newman-Keuls test, variances' comparisons by Levene's test, and comparison of frequency distribution by $\chi^{2}$-test indicated that the core collection was similar to that of the entire collection for various traits and the genetic variability available in the entire collection is preserved in the core collection. The Shannon-Weaver diversity index for different traits was also similar for both entire and core collection. All the important phenotypic associations between different traits available in the entire collection were preserved in the core collection. The core collection constituted in the present study facilitates identification of useful traits economically and expeditiously for use in pigeonpea improvement.
\end{abstract}

\section{Introduction}

Pigeonpea [Cajanus cajan (L.) Millspaugh], a major grain legume crop of tropics and subtropics, is grown as a field and/or a backyard crop in about 82 countries (Nene and Sheila 1990). However, only in 18 countries it is grown as a regular annual field crop on 4.2 million hectare, with a production of 3 million tons and a productivity of $0.72 \mathrm{t} \mathrm{ha}^{-1}$ (FAOSTAT 2003). India, Myanmar, and Nepal in Asia, Uganda and Tanzania in Africa, and Dominican Republic in Americas are the major pigeonpea producers. In India, which accounts for more than $80 \%$ world's pigeonpea production, the seed is primarily consumed as dhal (dried dehusked split cotyledons) and in Latin America the tender green seeds are used as canned peas. Various parts of pigeonpea plant are put to several other uses such as medicine, feed, fodder, fuel wood, hedges, windbreaks, roof thatches, and green manure. It also arrests soil erosion especially in sloping lands, and enriches the soil with organic content and provides nitrogen through symbiotic rhizobia. Due to these multiple uses of the crop, it plays an important role in subsistence agriculture.

In the past, majority of released pigeonpea varieties have been developed by pure line selection 
from the landraces for suitable maturity duration and disease resistance (Singh et al. 1990). For the last three decades, there has been increased emphasis in developing improved cultivars through hybridization. However, as in other crop improvement programs, the use of germplasm is still limited in pigeonpea for want of information on the specific traits of local importance. In order to effectively and economically maintain and utilize the world pigeonpea germplasm collections ( $>12,000$ accessions), a need to develop a more comprehensive classification based on both morphological and agronomic characters was suggested (Reddy 1990). A core subset derived from an existing collection comprises a chosen set of accessions that represent a wide cross-section of genetic spectrum available in a given crop species, with least amount of duplication. Such a core collection facilitates the genebank curators in doing a better job of assembly, management, and use of collections, particularly of indigenous genetic resources (Brown 1995). The core collection is of immense value in crop improvement programs, since due to its reduced size it can be evaluated extensively and more economically for required traits.

Since the original proposal of Frankel (1984), the rationale, purposes, and general principles of core collections have been investigated (Frankel and Brown 1984; Brown 1989a, b) and it was found that about $10 \%$ randomly drawn samples form the whole collection was relatively efficient in retaining of about $70 \%$ of its allelic variation (Brown 1995). Following this approach, core collections have been constituted in several crop species including grain legumes, such as common bean (Tohme et al. 1995), chickpea (Hannon et al. 1994; Upadhyaya et al. 2001a), groundnut (Holbrook et al. 1993; Upadhyaya et al. 2003), mungbean (Vigna radiata (L.) Wilcz.) (Bisht et al. 1998), and pea (Wojciech et al. 2000).

At Rajendra S. Paroda genebank, ICRISAT, Patancheru, India, 12,370 pigeonpea accessions have been assembled and conserved. Substantial characterization and evaluation data has been generated for several traits, including information on screening for the major stresses of pigeonpea during 1974-1998. The present study was undertaken to develop a pigeonpea core collection using data on 14 morphological descriptors.

\section{Material and methods}

The genebank at ICRISAT holds 12,370 pigeonpea accessions, which comprise mostly landraces, improved selections from the landraces, and breeding lines which are in trust following the agreement signed in 1994 with the Food and Agriculture Organization of the United Nations (FAO). Of these, 12,153 accessions from 56 countries, where most of the characterization information was available were used for developing the core subset. Data on 14 qualitative traits was considered for the formation of the core subset. These include: growth habit, plant pigmentation, flowering pattern, flower color, streak color, streak pattern, pod color, seed color pattern, primary seed color, secondary seed color, seed eye color, seed eye color width, seed shape, and seed hilum. All the above traits were recorded following the standard descriptors published by IBPGR and ICRISAT (1993). The global 12,153 pigeonpea accessions from 56 countries were placed under 14 groups, primarily on the basis of geographical origin. The accessions from small (geographically) and adjacent countries with similar agro-climate were grouped together following Brown (1989a). For India, where the pigeonpea crop has originated and extensively grown, the accessions from various provinces were formed into four broad groups. Based on the similar geographical and agroclimatic zones, the accessions from neighboring countries were clubbed with appropriate Indian provinces. Thus, the accessions from northwestern Indian provinces were grouped with those of Pakisthan and Iran; those from northeastern provinces with Myanmar and Nepal, and collections from southern provinces with Maldives and Sri Lanka. Accessions from central India and the Indian accessions with no information on the province of origin were formed into two separate groups. The other geographical groups included accessions from East Asia and Caucasus (three countries) Southeast Asia (three countries), Southern and Eastern Africa (nine countries), West Central Africa (seven countries), Americas (seven countries), Caribbean region (12 countries), Europe (four countries), and Oceania (one country). The accessions lacking information on country of origin were treated as a separate group. The data on the 14 morphological qualitative 
descriptors in each group was standardized following Milligan and Cooper (1985) to eliminate scale differences. The standardized data was subjected to the hierarchical cluster algorithm of Ward (1963) at $R^{2}$ (squared multiple correlation) equal to 0.75 , using SAS (SAS Institute 1989). This method optimizes an objective function by minimizing the sum of squares within groups and maximizing the sum of squares between groups. The agglomerative procedure starts with $n$ groups, that is, one observation in one group (maximum between-group sum of squares) and proceeds by merging observations in groups so that the between-groups sum of squares decreases and within-groups sum of squares increases. In certain cases, the within-groups sum of squares will remain the same but it will never decrease. From each cluster approximately 10\% accessions were randomly picked for inclusion in the core collection. At least one accession was included even from those clusters that had less than 10 accessions.

The means for the entire collection and core collection were compared using Newman-Keuls procedure (Newman 1939; Keuls 1952). The homogeneity of variances in the entire and core collection were compared for all the morphological descriptors and agronomic traits by Levene (1960) test. The distribution homogeneity for each of the morphological descriptors and agronomic traits was also analysed by the $\chi^{2}$-test. For the quantitative traits, classes were formed based on range and distribution in the entire collection using standard deviation. The observed number of accessions in the core collection in each class was determined, and was tested against expected number of accessions using the $\chi^{2}$-test. The diversity index $\left(H^{\prime}\right)$ of Shannon and Weaver (1949) was estimated and used as a measure of phenotypic diversity in the entire and the core collection for each trait. Phenotypic correlations were calculated for 14 qualitative and 17 quantitative traits among the entire and core collections independently, to see whether these associations which might be under genetic control, are conserved in the core collection or not.

\section{Results and discussion}

Based on 14 qualitative traits in the 12,153 accessions held in the ICRISAT genebank, a core collection comprising 1290 accessions $(10.6 \%$ of entire collection) was constituted. The mean, range, and variance for the 14 traits considered for core collection formation are given in Table 1. The means between entire collection and core collection was significantly different $(p=0.05)$ for only one trait, that is, plant pigmentation. For all the other 13 traits (growth habit, flowering pattern, flower color, streak color, streak pattern, pod color, seed color pattern, primary seed color, secondary seed color, seed eye color, seed eye color width, seed shape, and seed hilum) the means in the entire and core collection were similar. Among the 14 qualitative traits, the entire range $(100 \%)$ was preserved for 10 traits (growth habit, plant pigmentation, flowering pattern, flower color, streak color, streak pattern, pod color, seed color pattern, secondary seed color, and seed hilum) in the core subset (Table 1). For the remaining four traits (seed eye color, primary seed color, seed eye color width, and seed shape) the range varied from $88 \%$ to $98 \%$.

Comparison of the variances for the 14 qualitative traits (Table 1) in the entire and core collection, indicated non-homogeneity only for plant pigmentation $(p=0.010)$. The remaining 13 traits showed homogeneity for variance indicating the similarity between the entire and core collection. Among the traits not used in core formation, variances between entire and the core collections were homogeneous for all traits.

Of the 25 qualitative and quantitative traits, which were not considered for the selection of the core collection due to availability of scanty data, for 24 traits the means of entire and core collection were not significantly different (Table 2 ). The core and entire collection differed only for seeds per pod. It is noteworthy that the core and the entire collection did not differ for their mean in the important agronomic traits, that is, days to flowering, raceme number, days to maturity, shelling percentage, seed yield, harvest index, and reaction to all the three major diseases of pigeonpea [Phytophthora blight (Phytophthora drechsleri Tucker f.sp. cajani (Pal et al.) Kannaiyan et al.], sterility mosaic (caused by pigeonpea sterility mosaic virus (Kumar et al. 2003), and wilt (Fusarium udum Butler)]. Similar representation of the range was realized in the core subset for the traits that were not used in the development of core collection (data not given). For all the four 
Table 1. Comparison of mean ( \pm s.e.), ranges, and variance in the entire collection and core collection for various qualitative descriptors used in formation of core collection in pigeonpea.

\begin{tabular}{|c|c|c|c|c|c|c|c|c|c|}
\hline \multirow[b]{2}{*}{ Descriptor } & \multicolumn{3}{|l|}{ Mean } & \multicolumn{2}{|l|}{ Range } & \multicolumn{4}{|l|}{ Variance $^{4}$} \\
\hline & $\begin{array}{l}\text { Entire } \\
\text { collection }\end{array}$ & $\begin{array}{l}\text { Core } \\
\text { collection }\end{array}$ & Differences $^{1}$ & $\begin{array}{l}\text { Entire } \\
\text { collection }\end{array}$ & $\begin{array}{l}\text { Core } \\
\text { collection }\end{array}$ & $\begin{array}{l}\text { Entire } \\
\text { collection }\end{array}$ & $\begin{array}{l}\text { Core } \\
\text { collection }\end{array}$ & $F$ value & $p$ \\
\hline Growth habit & $3.6 \pm 0.01$ & $3.6 \pm 0.03$ & $\mathrm{NS}^{2}$ & $1.0-5.0$ & $1.0-5.0(100)^{3}$ & 1 & 1 & 0.16 & 0.69 \\
\hline Plant pigmentation & $1.2 \pm 0.01$ & $1.3 \pm 0.02$ & $*$ & $1.0-9.0$ & $1.0-9.0(100)$ & 0.4 & 0.7 & 6.68 & 0.01 \\
\hline Flowering pattern & $2.9 \pm 0.00$ & $2.9 \pm 0.01$ & NS & $1.0-3.0$ & $1.0-3.0(100)$ & 0.2 & 0.2 & 0.39 & 0.53 \\
\hline Flower color & $3.9 \pm 0.00$ & $3.9 \pm 0.01$ & NS & $1.0-6.0$ & $1.0-6.0(100)$ & 0.2 & 0.2 & 1 & 0.31 \\
\hline Streak color & $2.8 \pm 0.01$ & $2.8 \pm 0.02$ & NS & $1.0-7.0$ & $1.0-7.0(100)$ & 0.4 & 0.4 & 0.62 & 0.43 \\
\hline Streak pattern & $2.4 \pm 0.02$ & $2.4 \pm 0.08$ & NS & $1.0-25.0$ & $1.0-25.0(100)$ & 7.2 & 7.4 & 0.08 & 0.78 \\
\hline Pod color & $7.6 \pm 0.01$ & $7.5 \pm 0.04$ & NS & $1.0-13.0$ & $1.0-13.0(100)$ & 2.4 & 2.6 & 2.03 & 0.15 \\
\hline Seed color pattern & $2.6 \pm 0.03$ & $2.8 \pm 0.10$ & NS & $1.0-17.0$ & $1.0-17.0(100)$ & 12.3 & 13 & 0.45 & 0.50 \\
\hline Primary seed color & $8.2 \pm 0.12$ & $8.5 \pm 0.38$ & NS & $1.0-77.0$ & $1.0-73.0(95)$ & 172.5 & 182.2 & 0.19 & 0.66 \\
\hline Secondary seed color & $11.4 \pm 0.06$ & $11.3 \pm 0.17$ & NS & $1.0-26.0$ & $1.0-26.0(100)$ & 37.1 & 37.9 & 0.34 & 0.56 \\
\hline Seed eye color & $13.7 \pm 0.03$ & $13.6 \pm 0.10$ & NS & $1.0-45.0$ & $1.0-44.0(98)$ & 9.2 & 11.9 & 3.65 & 0.05 \\
\hline Seed eye color width & $1.3 \pm 0.01$ & $1.3 \pm 0.02$ & NS & $1.0-8.0$ & $1.0-7.0(88)$ & 0.4 & 0.5 & 3.05 & 0.08 \\
\hline Seed shape & $2.1 \pm 0.01$ & $2.1 \pm 0.02$ & NS & $1.0-13.0$ & $1.0-12.0(92)$ & 0.7 & 0.7 & 0.01 & 0.92 \\
\hline Seed hilum & $1.1 \pm 0.00$ & $1.1 \pm 0.01$ & NS & $1.0-2.0$ & $1.0-2.0(100)$ & 0.1 & 0.1 & 2.47 & 0.11 \\
\hline
\end{tabular}

${ }^{1}$ Differences between means of entire collection and core collection were tested by Newman-Keuls test.

${ }^{2} \mathrm{NS}$ and $*$ indicate non-significant or significant differences, respectively, at $p=0.05$.

${ }^{3} \%$ range retained in core collection.

${ }^{4}$ Variance homogeneity tested by Levene's test.

qualitative and three agronomic traits (disease reaction for Phytophthora, sterility mosaic, and wilt) and for four quantitative traits of agronomic importance (primary and tertiary branches, raceme number, and seed yield) $100 \%$ range was captured in the core collection. For the remaining 13 quantitative traits the range preserved in the core collection varied from $72 \%$ (for harvest index) to $98 \%$ (for pod number). Among the traits not used in the core formation, variances between entire and the core collections were homogeneous for all the traits (Table 2).

A comparison of frequency distribution and Shannon-Weaver diversity index in the entire and core collection for the various qualitative traits used in core collection formation is given in Table 3. The frequency distribution using $\chi^{2}$-analysis indicated homogeneity of distribution, for all the qualitative traits used in core formation, except for pod color $(p=0.0276)$ and seed eye color width $(p=0.0004)$. The Shannon-Weaver diversity index $\left(H^{\prime}\right)$ in the core collection was similar to the entire collection (Table 3) for all the 14 qualitative traits used in the core formation. The average $H^{\prime}$ in core subset was similar $(0.333 \pm 0.058)$ to that of the entire collection $(0.318 \pm 0.057)$.
A comparison of frequency distribution and Shannon-Weaver diversity index for the entire and core collection for the traits not used for core formation is given in Table 4. All the 25 qualitative, agronomic, and quantitative traits showed homogeneity of distribution, except for seed protein $(p=0315)$, The Shannon-Weaver diversity index $\left(H^{\prime}\right)$ was also similar in the core and entire collection for all the 25 traits. The average $H^{\prime}$ for these traits was $0.590 \pm 0.0136$ for entire collection and $0.582 \pm 0.0160$ for core collection (Table 4).

Phenotypic correlations were worked out for all the 14 qualitative traits used in the composition of core collection and for 17 quantitative traits that were not considered in the core formation independently. With more than 12,150 degrees of freedom, a large number of correlation coefficients which have an absolute value greater than 0.037 were significant at $p=0.0001$. However, only two correlation coefficients had an absolute value greater than 0.71 $\left(r^{2}=0.50\right)$; suggested by Skinner et al. (1999) for the meaningful associations. They were between days to flowering and days to maturity $(r=0.901$ in the entire collection; $r=0.928$ in the core collection) and raceme number and pod number $(r=0.908$ for entire collection; $r=0.889$ for core collection). 
Table 2. Comparison of mean ( \pm s.e.) and variance in the entire collection and core collection for various qualitative and quantitative descriptors not used in core collection formation in pigeonpea.

\begin{tabular}{|c|c|c|c|c|c|c|c|}
\hline \multirow[b]{2}{*}{ Descriptor } & \multicolumn{3}{|l|}{ Mean } & \multicolumn{4}{|l|}{ Variance $^{3}$} \\
\hline & Entire collection & Core collection & Differences $^{1}$ & Entire collection & Core collection & $F$ value & $p$ \\
\hline \multicolumn{8}{|l|}{ Qualitative traits } \\
\hline Plant vigour & $5.5 \pm 0.01$ & $5.5 \pm 0.04$ & $\mathrm{NS}^{2}$ & 1.6 & 1.5 & 0.48 & 0.489 \\
\hline Stem thickness & $5.5 \pm 0.01$ & $5.5 \pm 0.04$ & NS & 1.6 & 1.5 & 0.10 & 0.749 \\
\hline Leaf color & $1.0 \pm 0.00$ & $1.0 \pm 0.01$ & NS & 0.1 & 0.1 & 0.19 & 0.665 \\
\hline pod shape & $1.8 \pm 0.00$ & $1.8 \pm 0.01$ & NS & 0.2 & 0.2 & 3.09 & 0.101 \\
\hline Photoperiod response & $1.1 \pm 0.01$ & $1.1 \pm 0.02$ & NS & 0.6 & 0.6 & 0.06 & 0.800 \\
\hline \multicolumn{8}{|l|}{ Disease reaction } \\
\hline Phytophthora blight & $5.4 \pm 0.02$ & $5.3 \pm 0.08$ & NS & 1.4 & 1.6 & 0.10 & 0.753 \\
\hline Sterility mosaic & $5.5 \pm 0.02$ & $5.5 \pm 0.05$ & NS & 1.8 & 1.8 & 0.95 & 0.331 \\
\hline Wilt & $3.8 \pm 0.04$ & $3.8 \pm 0.12$ & NS & 2.4 & 2.2 & 2.54 & 0.111 \\
\hline \multicolumn{8}{|l|}{ Quantitative traits } \\
\hline Leaf size $\left(\mathrm{cm}^{2}\right)$ & $23.5 \pm 0.14$ & $23.5 \pm 0.46$ & NS & 46.0 & 49.9 & 0.99 & 0.321 \\
\hline Plant height $(\mathrm{cm})$ & $176.4 \pm 0.36$ & $176.7 \pm 1.12$ & NS & 1571 & 1612 & 0.09 & 0.761 \\
\hline Primary branches (no.) & $13.3 \pm 0.06$ & $13.1 \pm 0.19$ & NS & 42.0 & 45.0 & 1.45 & 0.229 \\
\hline Secondary branches (no.) & $30.6 \pm 0.17$ & $29.6 \pm 0.50$ & NS & 332 & 314 & 1.17 & 0.28 \\
\hline Tertiary branches (no.) & $9.2 \pm 0.11$ & $9.1 \pm 0.37$ & NS & 125 & 153 & 1.27 & 0.26 \\
\hline Days to flowering & $133.5 \pm 0.23$ & $134.4 \pm 0.72$ & NS & 660 & 666 & 0.04 & 0.847 \\
\hline Raceme (no.) & $145.9 \pm 0.85$ & $142.2 \pm 2.67$ & NS & 8455 & 8714 & 0.21 & 0.651 \\
\hline Days to maturity & $191.8 \pm 0.29$ & $192.7 \pm 0.88$ & NS & 1019 & 1002 & 0.21 & 0.646 \\
\hline Pod bearing length $(\mathrm{cm})$ & $36.4 \pm 0.17$ & $36.1 \pm 0.52$ & NS & 293.2 & 300.1 & 0.53 & 0.467 \\
\hline Pod length $(\mathrm{cm})$ & $5.8 \pm 0.01$ & $5.9 \pm 0.04$ & NS & 1.7 & 1.8 & 0.49 & 0.483 \\
\hline Pod/plant (no.) & $282.6 \pm 1.83$ & $272.7 \pm 5.48$ & NS & 35322 & 33622 & 0.34 & 0.558 \\
\hline Seeds per pod & $3.7 \pm 0.01$ & $3.8 \pm 0.02$ & $*$ & 0.35 & 0.4 & 2.63 & 0.105 \\
\hline 100 -seed weight $(\mathrm{g})$ & $9.3 \pm 0.03$ & $9.4 \pm 0.08$ & NS & 7.95 & 8.1 & 0.08 & 0.771 \\
\hline Shelling (\%) & $60.6 \pm 0.12$ & $60.7 \pm 0.36$ & NS & 155.7 & 159.8 & 0.02 & 0.879 \\
\hline Seed yield/plant (g) & $62.0 \pm 0.37$ & $61.2 \pm 1.24$ & NS & 1615 & 1969 & 0.23 & 0.635 \\
\hline Harvest index (\%) & $21.0 \pm 0.08$ & $20.9 \pm 0.25$ & NS & 75.6 & 77.7 & 0.11 & 0.738 \\
\hline Seed protein $(\%)$ & $21.3 \pm 0.02$ & $21.3 \pm 0.06$ & NS & 3.9 & 4.0 & 0.56 & 0.454 \\
\hline
\end{tabular}

${ }^{1}$ Differences between means of entire collection and core collection were tested by Newman-Keuls test.

${ }^{2} \mathrm{NS}$ and $*$ indicate non-significant or significant differences, respectively, at $p=0.05$.

${ }^{3}$ Variance homogeneity tested by Levene's test.

Table 3. Comparison of frequency of distribution and Shanon-Weaver diversity index in the entire collection and core collection for various qualitative descriptors used in core formation in pigeonpea.

\begin{tabular}{|c|c|c|c|c|c|}
\hline \multirow[b]{2}{*}{ Descriptor } & \multicolumn{3}{|c|}{ Frequency of distribution } & \multicolumn{2}{|c|}{ Shanon-Weaver diversity index } \\
\hline & No. of classes & $\chi^{2}$ & $p$ & Entire collection & Core collection \\
\hline Growth habit & 5 & 5.783 & 0.2159 & 0.221 & 0.217 \\
\hline Plant pigmentation & 9 & 15.446 & 0.051 & 0.225 & 0.249 \\
\hline Flowering pattern & 3 & 0.449 & 0.7989 & 0.105 & 0.11 \\
\hline Flower color & 5 & 9.109 & 0.0584 & 0.111 & 0.126 \\
\hline Streak color & 7 & 4.306 & 0.6354 & 0.163 & 0.17 \\
\hline Streak pattern & 25 & 25.337 & 0.3876 & 0.631 & 0.642 \\
\hline Pod color & 13 & 23.012 & 0.0276 & 0.282 & 0.299 \\
\hline Seed color pattern & 17 & 11.614 & 0.7701 & 0.551 & 0.574 \\
\hline Primary seed color & 76 & 56.421 & 0.9461 & 0.787 & 0.811 \\
\hline Secondary seed color & 22 & 10.373 & 0.9737 & 0.438 & 0.446 \\
\hline Seed eye color & 42 & 52.5 & 0.1075 & 0.388 & 0.424 \\
\hline Seed eye color width & 8 & 26.576 & 0.0004 & 0.261 & 0.277 \\
\hline Seed shape & 13 & 9.029 & 0.7005 & 0.139 & 0.156 \\
\hline Seed hilum & 2 & 2.849 & 0.0914 & 0.145 & 0.158 \\
\hline Average \pm s.e. & & & & $0.318 \pm 0.057$ & $0.333 \pm 0.058$ \\
\hline
\end{tabular}


Table 4. Comparison of frequency of distribution and Shann-Weaver diversity index in the entire collection and core collection for various qualitative and quantitative descriptors not used in core formation in pigeonpea.

\begin{tabular}{|c|c|c|c|c|c|}
\hline \multirow[b]{2}{*}{ Descriptor } & \multicolumn{3}{|c|}{ Frequency distribution } & \multicolumn{2}{|c|}{ Shannon-Weaver diversity index } \\
\hline & No. of classes & $\chi^{2}$ & $p$ & Entire collection & Core collection \\
\hline \multicolumn{6}{|l|}{ Qualitative traits } \\
\hline Plant vigour & 3 & 0.536 & 0.7651 & 0.407 & 0.402 \\
\hline Stem thickness & 3 & 3.118 & 0.2104 & 0.403 & 0.400 \\
\hline Leaf color & 3 & 0.226 & 0.893 & 0.037 & 0.034 \\
\hline Pod shape & 2 & 3.679 & 0.0551 & 0.224 & 0.236 \\
\hline Photoperiod response & 2 & 0.956 & 0.3281 & 0.098 & 0.121 \\
\hline Phytophthora blight & 6 & 1.336 & 0.9312 & 0.423 & 0.406 \\
\hline Sterility mosaic & 6 & 2.951 & 0.7075 & 0.323 & 0.305 \\
\hline Wilt field & 6 & 4.952 & 0.4218 & 0.639 & 0.583 \\
\hline Average \pm s.e. & & & & $0.324 \pm 0.061$ & $0.322 \pm 0.056$ \\
\hline \multicolumn{6}{|l|}{ Quantitative traits } \\
\hline Leaf size $\left(\mathrm{cm}^{2}\right)$ & 9 & 5.08 & 0.7489 & 0.61 & 0.601 \\
\hline Plant height $(\mathrm{cm})$ & 7 & 2.88 & 0.8237 & 0.626 & 0.634 \\
\hline Primary branches (no.) & 16 & 12.93 & 0.6076 & 0.589 & 0.571 \\
\hline Secondary branches (no.) & 8 & 11.47 & 0.1193 & 0.592 & 0.588 \\
\hline Tertiary branches (no.) & 20 & 7.03 & 0.994 & 0.396 & 0.351 \\
\hline Days to flowering & 8 & 7.59 & 0.3705 & 0.626 & 0.624 \\
\hline Raceme (no.) & 10 & 6.93 & 0.6448 & 0.57 & 0.556 \\
\hline Days to maturity & 7 & 2.68 & 0.8477 & 0.643 & 0.632 \\
\hline Pod bearing length $(\mathrm{cm})$ & 7 & 6.48 & 0.3721 & 0.61 & 0.595 \\
\hline Pod length $(\mathrm{cm})$ & 9 & 5.21 & 0.7351 & 0.608 & 0.593 \\
\hline Pod/plant (no.) & 10 & 4.31 & 0.8898 & 0.559 & 0.551 \\
\hline Seeds per pod & 9 & 8.21 & 0.4133 & 0.588 & 0.605 \\
\hline 100 -seed weight $(\mathrm{g})$ & 9 & 4.57 & 0.8022 & 0.566 & 0.57 \\
\hline Shelling percentage & 8 & 7.97 & 0.3353 & 0.626 & 0.626 \\
\hline Seed yield/plant (g) & 17 & 15.95 & 0.4562 & 0.568 & 0.555 \\
\hline Harvest index $(\%)$ & 9 & 1.56 & 0.9918 & 0.627 & 0.622 \\
\hline Seed protein $(\%)$ & 10 & 18.33 & 0.0315 & 0.624 & 0.628 \\
\hline Average \pm s.e. & & & & $0.590 \pm .0136$ & $0.582 \pm 0.0160$ \\
\hline
\end{tabular}

The core collection presented here conserves all the phenotypic correlations (data not shown) observed in the entire collection. Further, the relationship observed between days to flowering and days to maturity in this study suggests that there may not be a need to record days to maturity in all the future germplasm evaluations, especially in areas where severe pod borer damage occurs and no stringent measures are undertaken for timely control of the pest. In such cases, the indeterminate nature of the pigeonpea crop with multiple flowering peaks could result in erroneous recording of observations on days to maturity. Hence, days to flowering could be used to predict the maturity duration. Other correlations with a magnitude less than 0.71 may be of interest to breeders. Such traits with moderate associations in the core collection include pod number with secondary branches $(r=0.664)$ and seed yield $(r=0.637)$, raceme number with seed yield $(r=0.554)$, secondary $(r=0.639)$, and tertiary $(r=0.531)$ branches, seed yield with secondary branches $(r=0.417)$, harvest index with shelling percentage $(r=0.532)$, and 100-seed weight with leaf size $(r=0.498)$ and pod length $(r=0.498)$. These observations indicate that the essential co-adapted gene complexes, which might be responsible for the above correlations, are adequately preserved in the core collection for the exploitation by the breeder in the crop improvement programs.

So far, only a small fraction of the germplasm has been utilized in pigeonpea crop improvement programs. In the developing countries, where mostly pigeonpea is grown as a subsistence crop, the resources allocated for crop improvement are too meager to take up extensive evaluations. The core collection can be economically and effectively utilized in identifying traits of importance. For 
example, the P2 isolate of Phytophthora drechsleri causing Phytophthora blight disease leads to severe mortality in the major pigeonpea growing areas in northern India. About 2600 accessions have been screened and no resistance sources identified. Screening for resistance in the rest of the 10,000 germplasm available at ICRISAT, will take about 8 years, in addition to the involvement of significant resources. However, the core collection will allow us to estimate the genetic variability available in the entire germplasm in one year and possibly help us identify the resistant sources with reduced costs and time. Hence, a manageable core subset can be evaluated for requisite traits of local importance, as an entry point. Such core collections in grain legume crops have already facilitated specific evaluations such as for disease resistance (e.g., late leaf spot resistance (Holbrook and Anderson 1995) and Rhizoctonia limb rot (Frankel et al. 1999) in groundnut; resistance to white mold in common bean (Micklas et al. 1999), and resistance for fusarium wilt race 2 in Pisum (McPhee et al. 1999); and for other agronomic traits (e.g., early maturity in groundnut (Upadhyaya et al. 2001b), and seed size and early maturity in chickpea (H.D. Upadhyaya, unpubl. data)]. Also, a core collection of pea facilitated identification of isozyme markers useful in chromosome mapping (Wojciech et al. 2000).

Pigeonpea research carried out in the last 30 years by ICRISAT and the other national programs has helped to produce short-duration (90120 days) pigeonpea which facilitated in extending its cultivation in new cropping systems and increased its adaptability from $30^{\circ}$ to $45^{\circ} \mathrm{N}$ latitude. Varieties with resistances to the three major diseases [Wilt (Fusarium udum Butler), pigeonpea sterility mosaic disease (caused by pigeonpea sterility mosaic virus (Kumar et al. 2003), and phytophthora blight (Phytophthora drechsleri Tucker f.sp. cajani (Pal et al.) Kannaiyan et al.] have been identified. However, due to occurrence of pathotypes or virulent stains (e.g., P4 isolate of Phytophthora blight), resistance to these diseases has broken down (Reddy et al. 1990). Also, pigeonpea germplasm accessions were not adequately evaluated for abiotic stresses such as tolerance to acid soils, salinity, water logging; and for cooking quality. Similarly for biotic stresses of regional importance (e.g., Cercospora leaf spots (Cercospora spp.), pod fly (Melanogromyza obtusa (Malloch), and pod sucking bugs (Clavigralla spp.) in Eastern Africa), sources of resistance for use in breeding programs are required. In such cases the pigeonpea core germplasm subset constituted in the present study can be utilized for finding resistance sources. Also, a core germplasm subset can be utilized economically for genomics research, and the latter in turn can result in better strategies for developing, validating, and revising a core collection (Jackson et al. 1999).

The list of pigeonpea accessions included in the core subset with the details on country of origin, ICP number, and the cluster number are available on diskette from the corresponding author.

\section{References}

Bisht I.S., Mahajan R.K. and Patel D.P. 1998. The use of characterization data to establish the Indian mungbean core collection and assessment of genetic variability. Genet. Resour. Crop Evol. 45: 127-133.

Brown A.H.D. 1989a. The case for core collections. In: Brown A.H.D., Frankel O.H., Marshall D.R. and Williams J.T. (eds), The Use of Plant Genetic Resources, Cambridge University Press, Cambridge, pp. 136-155.

Brown A.H.D. 1989b. Core collections: a practical approach to genetic resources management. Genome 31: 818-824.

Brown A.H.D. 1995. The core collection at the crossroads. In: Hodkin T., Brown A.H.D., van Hintum J.L. and Morales E.A.V. (eds), Core Collections for Today and Tomorrow, International Plant Genetic Resources Institute (IPGRI), Rome, Italy, Wiley-Sayce Publication, pp. 3-19.

Food and Agriculture Organization, 2003. FAOSTAT database http://www/FAO.ORG.

Frankel O.H. 1984. Genetic perspective of germplasm conservation. In: Arber W., Llimensee K., Peacock W.J. and Starlinger P. (eds), Genetic Manipulations: Impact on Man and Society, Cambridge University Press, Cambridge, pp. 161-170.

Frankel O.H. and Brown A.H.D. 1984. Current plant genetic resources - a critical appraisal. In: Chopra V.L., Joshi B.C., Sharma R.P. and Bansal H.C. (eds), Genetics: New Frontiers, Vol. IV. Oxford and IBH Publ. Co., New Delhi, pp. 1-13.

Frankel M.D., Brennman T.B. and Holbrook C.C. 1999. Identification of resistance to Rhizoctonia limb rot in a core collection of peanut germplasm. Plant Dis. 83: 944-948.

Hannon R.M., Kaizer W.J. and Muehlbauer F.J. 1994. Development and utilization of the USDA chickpea germplasm core collection. In: Agronomy Abstacts, ASA, Madison, WI, USA, p. 217.

Holbrook C.C. and Anderson W.F. 1995. Evaluation of a core collection to identify resistance to late leafspot in groundnut. Crop Sci. 35: 1700-1702. 
Holbrook C.C., Anderson W.F. and Pittman R.N. 1993. Selection of core collection from the U.S. germplasm collection of peanut. Crop Sci. 33: 859-861.

IBPGR and ICRISAT, 1993. Descriptors for pigeonpea [(Cajanus cajan (L.) Millsp.]. International Board for Plant Genetic Resources, Rome, Italy, International Crops Research Institute for the Semi-Arid Tropics, Patancheru, India.

Jackson M.T., Pham J.L., Newbury H.J., Ford-Lloyd B.V. and Virk P.S. 1999. A core collection for rice-needs, opportunities, and constraints. In: Johnson R.C. and Hodkin T. (eds), Core Collections for Today and Tomorrow, International Plant Genetic Resources Institute, Rome, Italy, pp. 18-27.

Keuls M. 1952. The use of the "Studentized range" in connection with an analysis of variance. Euphytica 1: 112-122.

Kumar P.L., Jones A.T. and Reddy D.V.R. 2003. A novel mitetransmitted virus with a divided RNA genome closely associated with pigeonpea sterility mosaic disease. Phytopathology 93: 81-91.

Levene H. 1960. Robust tests for equality of variances. In: Olkin I. (ed.), Contributions to Probability and Statistics: Essays in Honour of Harold Hotelling, Stanford University Press, Stanford, USA, pp. 278-292.

McPhee K.E., Tullu A., Kraft J.M. and Muehlbauer F.J. 1999. Resistance to Fusarium wilt race 2 in the Pisum core collection. J. Amer. Soc. Horti. Sci. 124: 28-31.

Micklas P.N., Delorme R., Hannan R. and Dickson M.H. 1999. Using a sub sample of the core collection to identify new sources of resistance to white mold in common bean. Crop Sci. 39: 569-573.

Milligan G.W. and Cooper M. 1985. An examination of procedures for determining the number of clusters in a data set. Psychometrica 50: 159-179.

Nene Y.L. and Sheila V.K. 1990. Pigeonpea: Geography and importance. In: Nene Y.L., Hall S.D. and Shiela V.K. (eds), The pigeonpea, C.A.B International, Wallingford, Oxon OX 10 8DE, UK, pp. 1-14.

Newman D. 1939. The distribution of range in samples from a normal population expressed in terms an independent estimate of standard deviation. Biometrika 31: 20-30.

Reddy L.J. 1990. Pigeonpea: morphology. In: Nene Y.L., Hall S.D. and Shiela V.K. (eds), The Pigeonpea, C.A.B International, Wallingford, Oxon OX10 8DE, UK, pp. 44-87.
Reddy M.V., Sharma S.B. and Nene Y.L. 1990. Pigeonpea: Disease Management. In: Nene Y.L., Hall S.D. and Shiela V.K. (eds), The Pigeonpea, C.A.B. International, Wallingford, Oxon OX10 8DE, UK, pp. 303-347.

SAS Institute, 1989. SAS/STAT User' Guide Version 6, 4th edn. SAS Institute, Inc., Cary, NC, USA.

Shannon C.E. and Weaver W. 1949. The mathematical theory of communication. University Illinois Press, Urbana, USA.

Singh L., Gupta S.C. and Faris D.G. 1990. Pigeonpea Breeding. In: Nene Y.L., Hall S.D. and Shiela V.K. (eds), The Pigeonpea, C.A.B. International, Wallingford, Oxon OX10 8DE, UK, pp. 375-399.

Skinner D.Z., Bauchan G.R., Auricht G. and Hughes S. 1999. A method for the efficient management and utilization of large germplasm collections. Crop Sci. 39: 1237-1242.

Tohme J., Jones P., Beebe S. and Iwanga M. 1995. The combined use of agroecological and characterization data to establish the CIAT Phaseolus vulgaris core collection. In: Hodkin T., Brown A.H.D., van Hintum Th.J.L. and Morales B.A.V. (eds), Core Collection of Plant Genetic Resources, International Plant Genetic Resources Institute (IPGRI), John Willey \& Sons, New York, USA, pp. $95-108$.

Upadhyaya H.D., Bramel P.J. and Singh S. 2001a. Development of a chickpea core subset using geographic distribution and quantitative traits. Crop Sci. 41: 206-210.

Upadhyaya H.D., Ferguson M.E. and Bramel P.J. 2001b. Status of the Arachis germplasm collection at ICRISAT. Peanut Sci. 28: 89-96.

Upadhyaya H.D., Ortiz R., Bramel P.J. and Singh S. 2003. Development of a groundnut core collection using taxonomical, geographical, and morphological descriptors. Genet. Resour. Crop Evol. 50: 139-148.

Ward J. 1963. Hierarchical grouping to optimize an objective function. J. Amer. Stat. Assoc. 38: 236-244.

Wojciech K., Bogdan W., Somsak A. and Pawe K. 2000. An analysis of isozymic loci polymorphism in the core collection of the Polish Pisum genebank. Genet. Resour. Crop Evol. 47: 583-590. 